\title{
Public sector reputation and netpromoter score
}

\author{
Vilma Luoma-aho ${ }^{1}$ (D) María José Canel ${ }^{2}$ • Juho Hakola ${ }^{3}$
}

Received: 4 June 2020 / Accepted: 3 February 2021 / Published online: 16 March 2021

(C) The Author(s) 2021, corrected publication 2021

\begin{abstract}
Reputation of public sector organizations is increasingly formed through Word of Mouth (WOM) as citizens and stakeholders share their experiences with others both online and offline. Understanding and measuring WOM is a challenge for many public sector organizations, who often resort to measurement tools designed for the private sector. This paper looks at a popular WOM measurement tool, namely the Net Promoter Score (NPS) in the context of public sector organizations. In this paper, we ask how well does the NPS describe public sector reputation, and look at what the different stakeholder groups categorized by NPS are like in the public sector. As an illustrative case, we report findings of a stakeholder reputation survey (n: 1198) conducted for a large Finnish ministry utilizing both established reputation measures and the NPS. Based on our findings, we conclude that the traditional NPS requires tailoring to match the public sector context, and propose "The Public Sector Net Promoter Score (PSNPS)" as a new measure for WOM in the public sector context.
\end{abstract}

Keywords Public sector - NPS · Net Promoter Score - Reputation · Stakeholders · Feedback · Survey

\section{Introduction}

What citizens and individuals say about public sector organizations is central for western democracy, as engaged and communicative citizens improve the overall quality of public services (Dahlberg and Holmberg 2013; Delli Carpini et al. 2004; Gelders et al. 2007). Moreover, the type and level of trust that citizens feel toward public sector organizations has been suggested to radiate into the society beyond the initial context, and as such be of interest for public managers (Rothstein and Uslaner 2005).

Vilma Luoma-aho

vilma.luoma-aho@jyu.fi

1 School of Business \& Economics, University of Jyväskylä, Jyväskylä, Finland

2 Complutense University of Madrid, Madrid, Spain

3 City of Vantaa, Finland 
As the operating environment for public sector organizations becomes increasingly digital, citizen expectations have changed (Canel and Luoma-aho2019, 129; Etter et al. 2019). Despite this, many public sector organizations still rely on traditional means of citizen feedback when developing the public services. Moreover, current forms of engaging citizens in service development or co-creation of public services remains a legibility challenge, as public sector organizations in their communication "..generally impose a heavy cognitive load on citizens and open the door for strategies of obfuscation of various types" (Picci 2012, 142). Citizen-centric services and hence citizen centric feedback channels have been called for to better serve the new expectations of citizens (Bourgon 2009).

Stakeholders, understood as individuals and groups without whose support an organization would cease to exist (Freeman and Reed 1983) are complex and dynamic in the public sector. Ranging from individual citizens and service users to different collaboration network partners and multinational public, non-profit and private organizations, the stakeholders of public sector organization are a diverse group, challenging to measure and understand (Canel and Luoma-aho2019). Unlike businesses or NGOs that can more easily tailor their services to specific needs and issues, the public sector is often guided by national legislation, and under democratic order required to serve all citizens despite their diverse backgrounds (eg. language, age, geographical location), needs, and even in some services, general unwillingness to collaborate or receive public services. Furthermore, not only these diverse citizens have to be addressed by public sector organizations, but also different types of stakeholders: private companies, international bodies, service-provider organizations (such as schools, hospitals and museums), or labor unions. Public sector organizations therefore need to be able to balance and reconcile conflicting objectives coming from more established and emerging stakeholders (Gelders et al. 2007).

Building on Waeraas and Maor (2015), we understand public sector reputation to result from both organizational actions and social negotiations. To the extent that reputation lays on stakeholders' acknowledgement of organizational behavior, it is also the activation of perceptions via communication that matters for reputation (Canel and Luoma-aho2019). Reputation is increasingly formed in the online environment, where stakeholders share their experiences with peers (Eisingerich et al. 2015; Etter et al. 2019). Despite this, few reputation measurement tools are well suited to capture ad hoc citizen experiences as to provide the public sector organizations a peek into their reputation. More understanding is needed on the measures which we use to evaluate public services, and how ideas originating from industry apply in the public sector (De Cnudde and Martens 2015).

This paper looks at a popular WOM measurement tools from the private sector, namely the Net Promoter Score (Reichheld 2003). NPS asks citizens or stakeholders: "On a scale of 1-10, how likely would you recommend this organization/service to others?" Based on their answer, NPS divides respondents into three distinct groups: promoters, detractors and passives. Although NPS has been criticized for its overtly simplistic structure (Kristensen and Eskildsen 2014), it remains one of the most commonly used metrics in private sector organizations. In this paper, we discuss the suitability of NPS to the public sector context. This research seeks to answer how well does the NPS describe public sector reputation, and asks what the public sector promoters and detractors are like.

This paper is organized as follows: First, we address public sector WOM and reputation, and look into reputation measurement. Second, we introduce the 
netpromoter score and the main groups resulting from the NPS: promoters and detractors. This study is based on empirical observation, and for that we compare findings of a stakeholder reputation survey conducted for a large Finnish ministry utilizing both more established measures of public sector reputation (Luoma-aho 2007, 2008) and the NPS (Reichheld 2003) in 2016. Our results point to more similarities than differences between the different tools, but there are certain specific traits only applicable to the public sector that the NPS ignores. Therefore, we propose a specific new measure for public sector netpropmotor score: the PSNPS. To conclude, we discuss the adoption of the PSNPS for reputation measurement and highlight future research lines regarding several dilemmas related to NPS adaptation and utilization.

\section{Word of mouth in the public sector}

Word of mouth (WOM) refers to unofficial messages and experiences from a citizen to another (East et al. 2008) or sharing of opinions and recommendations (Berger 2014; Martin 2017). There are several functions which WOM fulfills in individuals (Berger 2014). First, WOM serves the purpose of information sharing and persuasion, where individuals seek advise and opinions to solve problems and make decisions. Second, WOM is about sharing experiences serves as a type of impression management, where the individual shares experiences to self-enhance and signal their identity to establish common ground and entertainment for others. WOM also serves the purpose of emotion regulation, where individuals vent to reduce dissonance and gain social support from others. Further, WOM serves the function of social bonding where individuals build common ground and reduce loneliness and reinforce shared views (Berger 2014).

WOM may either be positive (PWOM, where individuals tell of their positive experiences and recommend the organization) or negative (NWOM, where individuals tell of their negative experiences and warn about the organization). Its power lies in its credibility, influence on purchases and link with satisfaction (East et al. 2008; Sweeney et al. 2014). As services digitalize, WOM has also moved to online environments and social media (Eisingerich et al. 2015). Due to its wider reach, online WOM (social WOM, sWOM) is seen as more influential than traditional WOM (Sun et al. 2006). Despite its popularity, individuals are less likely to share social media originated WOM than traditional WOM, possibly due to credibility issues. Moreover, individuals are less willing to provide positive feedback for organizations in social media than face-to-face, due to perceived social risk and in self-enhancement, where sharing SWOM can be seen as more risky and more sensitive to motives to enhance self (Eisingerich et al. 2015). WOM has been suggested to contribute to organizational reputation, and hence we next look at public sector reputation.

\section{Public sector reputation}

The idea of developing reputation in the public sector is to better understand the relationship that public sector organizations have with their stakeholders. Customer relationship management (CRM) thinking originates from the private sector, dynamic 
and knowledge- intensive learning organizations (Riege and Lindsay 2006, 25). Moreover, the aim of CRM as philosophy is to connect with customer/stakeholder in day-today actions and understanding the needs and the demands of the customers, that may change during time (Zablah et al. 2004, 480).

Public sector has been defined through the three functions it serves: enabling economic development, control of society and its security, as well as providing public value (Canel and Luoma-aho2019). As social media continues to take over citizen and stakeholder interaction, fundamental shift is occurring in the formation of reputation. Whereas many public sector organizations traditionally have relied on top-down organization controlled information dissemination, the new social horizontal social networks now take over as information is co-produced independently, and various citizens as sources offer their experience as a source (Etter et al. 2019). A good public sector reputation is important, as public sector reputations affect larger entities beyond their immediate services provided: "Globalization, standardization, and marketization of public sector services not only put the reputations of central and local government agencies at stake, but also those of the entire public sector and the nation" (Sataøen and Wæraas 2016, 165). This is particularly challenging for public sector organizations, as poor reputation may cause life-threatening public messages from being acknowledged.

In fact, reputation of public sector organizations has received greater public manager attention as the legitimacy of public organizations increasingly rests upon how the organization is perceived by the diverse stakeholders around it (Walker et al. 2011; Boon and Salomonsen 2020). This major role played by citizen impressions is increasing due to citizens' ability to share information online, as well as the various online reputation systems to compare experiences (Canel and Luoma-aho2019, 129). However, research suggests that what happens online is not always the same as offline, though in both instances personal recommendations play a major role (Eisingerich et al. 2015). Moreover, in social media it is especially relevant for effectiveness how the content or service is introduced (Luoma-aho et al. 2019b; Munnukka et al. 2019).

Public Sector reputation has been defined as "collective assessment of the organization by both the mediated and personal experiences of stakeholders that results from the stakeholders' expectations and shapes their attitudes and trust toward and their collaboration with the organization and more broadly the sector in which that organization operates" (Canel and Luoma-aho2019, 125). The mediated experiences can range from reports of legacy media to informal peer discussion on social media (Etter et al. 2019), but they shape citizen attitudes and expectations and hence enable or hinder collaboration between public sector organizations and citizens.

Public sector managers borrow instruments from the private sector to measure intangible value and reputation (Sataøen and Wæraas 2016; Wæraas and Byrkjeflot 2012; Bankins and Waterhouse 2019; Overman et al. 2020). For instance, municipalities are using reputation barometers built for the private sector to measure city reputation; public health organizations are applying satisfaction surveys to hospitals; and public organizations are deploying corporate social responsibility measures which derive from the private sector (Canel and Luoma-aho2019). The degree of publicness or privateness actually varies also among public sector organizations, and Canel and Luoma-aho(2019) suggest publicness to result from a 'fan' of 8 factors: funding, control, ownership, purpose, values, accountability, employees and profit. Despite the 
degrees of similarity, there remain clear contextual differences between reputation formation of private and public sector organizations (Luoma-aho 2008). Tied to its political context, public sector organizations are never totally independent to develop their reputation as they please (Luoma-aho and Canel 2016; Luoma-aho et al. 2020). Overall researchers agree that public sector faces more diverse stakeholders and needs, and there is less choice in whom to serve or select to provide the service (Sataøen and Wæraas 2016). This is very different from the private sector, where many reputation measurement tools focus on prioritizing brands and services by individual preference and experience. In addition, there are certain sector based reputational stigmas that public sector organizations globally battle (Luoma-aho 2008). Traits such as excess bureaucracy and inflexibility are traditionally parts of public sector organizations' reputation despite their efforts to modernize and transform their services (Wæraas and Byrkjeflot 2012). In fact, Waeraas et al. note conceptually several dilemmas related to reputation in the public sector: political nature of the context, consistency, charisma, uniqueness and excellence related challenges. These dilemmas have been tested in different organizations and contexts, such as universities (Kuoppakangas et al. 2019).

The politics problem refers to the political nature of the public sector. All public sector organizations remain political in nature as their agenda is set by political decision makers. In fact, sometimes public agencies are used as scapegoats or tools to gain political goodwill of citizens. Political and public sector communication, however, are not the same. Though they both aim at maintaining democracy and contribute to stability in society, political communication is about "political processes, systems and institutions" (Luoma-aho et al. 2019a, 113), whereas public sector communication is "goal-oriented communication inside organizations and between organizations and their stakeholders, that enables public sector functions within their specific cultural and/or political settings, with the purpose of building and maintaining the public good and trust between citizens and authorities" (Canel and Luoma-aho2019, 33).

Reputation for political and public sector organizations is formed differentlywhereas public sector organizations often represent neutral and order type organizations (ministries, regulatory agencies, research institutions) serving the general public, political organizations (and their leaders, the charisma problem), mostly serve a more specific values-based group of political thought. Hence, the sector reputation for political and public sector organizations results from different processes. For political communication, election cycles and campaign like settings shape the communication, and the role of individual leaders and what they stand for or stand against is emphasized (Luoma-aho et al. 2019a). Reputation of political organizations, therefore, rests much on the reputation of the political leaders and parties, and a good reputation may result among individuals from merely agreeing with the views of what the party represents. As for public sector organizations, political ideals and leaders play a smaller role, and the center stage is taken by the efficiency of the organization. Further, each public or political organization has been established for a purpose or mission independent on the public perception. This mission will also shape the organization's reputation. Reputation of a public agency may also be used as a political tool as criticizing public organizations efficiency may help political parties to gain favor of citizens (Wæraas and Byrkjeflot 2012).

Other challenges to reputation in the context of public sector include excellence, consistency and uniqueness (Wæraas and Byrkjeflot 2012). Whereas businesses are 
able to tailor their services to ideally match customer demands, public sector services exist to help all citizens and serve the public good. Mismatches in citizen expectations can be reflected in reputation, and the public organization may have little room to maneuver. Whereas political organizations reputation often relies on the charisma of their leaders, building such positive personal resonance is challenging for public sector organizations. In fact, a strong, charismatic leader could be seen as problematic, as attention would be targeted in a wrong direction, away from the organizational functions toward an individual. Further, in the public sector there is no premium available in the services, as one size mostly will serve all, and differentiation may in fact cause lack of trust. For the maintenance of trust, Luoma-aho(2007) suggests that neutral reputation might benefit public sector organizations more than a unique, strong reputation that could cause expectations to become too high and lead to disappointments. Maintaining a distinct, strong reputation demands great (even unrealistic) resources from public organizations with dwindling finances (Luoma-aho 2007).

Canel \& Luoma-aho $(2019,128)$ portray how public sector organizations' reputation is a balance between two continuums: between strong and vague reputation, and between unique and similar reputation. The benefits of each extreme are clear: if a public sector organization has a strong reputation, it will act as a strong brand promise, whereas a vague reputation will make it easy to fit in. A unique reputation will make the organization distinct from others while a similar reputation to other organizations will enable conformity. Similarly, there are challenges in each extreme, as ranging between too strong reputation that locks in high expectations that may be failed in practice, and too vague reputation that risks losing legitimacy, whereas a unique reputation risks standing out too much and a too similar reputation risks not being known at all which could prove challenging. They (Canel and Luoma-aho2019, 129) suggest the ideal reputation zone for public sector organizations to be somewhere in the middle, where expectations of stakeholder remain manageable and organizational isomorphism protects the organizations.

\section{Reputation measurement}

Research on reputation has been categorized into three perspectives, that could help understand public sector reputation (Wæraas and Maor 2015): Reputation as asset, where measuring reputation would be measuring the intangible asset; Reputation as a collective negotiated construction, where measuring reputation would refer to measuring those collective views; and reputation as institutional rankings, where the rankings would measure reputation. Whatever the view, reputation is argued to be an aggregate formed from individuals balancing between available information and their own experiences (Deephouse 2000), and because of this, reputation is constantly vulnerable to change (Walker 2010).

Originating from citizen satisfaction surveys, reputation measurement tools are often utilized by public sector managers mostly for internal development purposes (Thijs 2011). As such, the data collected is not always available for scientific studies, and much of current reputation measurement takes place via tools and barometers borrowed from the private sector (Luoma-aho 2007; Bankins and Waterhouse 2019; Overman et al. 2020). This is problematic, as reputation measurement is always organization 
specific: reputation is about seeing if the organizational goals set have been met. In fact, when it comes to measuring public sector reputation, one-size does not fit all, and context should always be considered. Reputation measures report the intangible capital accumulated from experiences, and to fully understand how they are formed several ethical questions should be asked: Do the citizens have actual experiences to report? Does reporting on them make their position stronger or more vulnerable? How has the media portrayed the organization? How is the context where the respondent is answering the survey shaping the answers (Thijs 2011).

Canel and Luoma-aho(2019, 130) categorize reputation measurement ways according to the amount of competition: when competition is low as in the case of public sector regulators or customs, neutrality is the ideal in reputation measurement (Luomaaho 2007): sufficiently meeting stakeholder needs. Where competition is high in the public sector, such as cities or universities, uniqueness becomes the focal point of reputation, and measuring reputation requires comparisons between other players in the same field. The challenging issue is "loyalty", as many public sector organizations customers do not freely "choose" their loyalty to the organization. Figure 1 illustrates this continuum.

As for the scales used in public sector reputation measurement, they are often tailored and validated for specific sector or organizational needs. Luoma-aho(2007, 2008) developed a scale for authority, legislative, regulatory and semi-commercial public sector organizations' stakeholders, whereas Lee and Van Ryzin (2019) suggest a more condensed Bureaucratic Reputation Scale (BRS). The Luoma-aho scale builds several semantic differential questions on statements around 5 reputational factors: Authority (for example, statements include bureaucratic-flexible), Esteem (eg. Not appreciated- appreciated), Trust (eg. unfair-fair), Service (useless-useful) and Efficiency (ineffective- effective) (Luoma-aho 2008). BRS combines 5-10 questions on 5 reputational dimensions: General (eg. Overall, this agency has a good reputation), Performance (well-run), Moral (maintains high ethical standards), Procedure (treats people fairly) \& Technical (bases decisions on evidence) (Lee and Van Ryzin 2019). Vochin et al. (2020) in their conference paper used NPS values of employees and clients of public sector organizations and asked about what changes they would

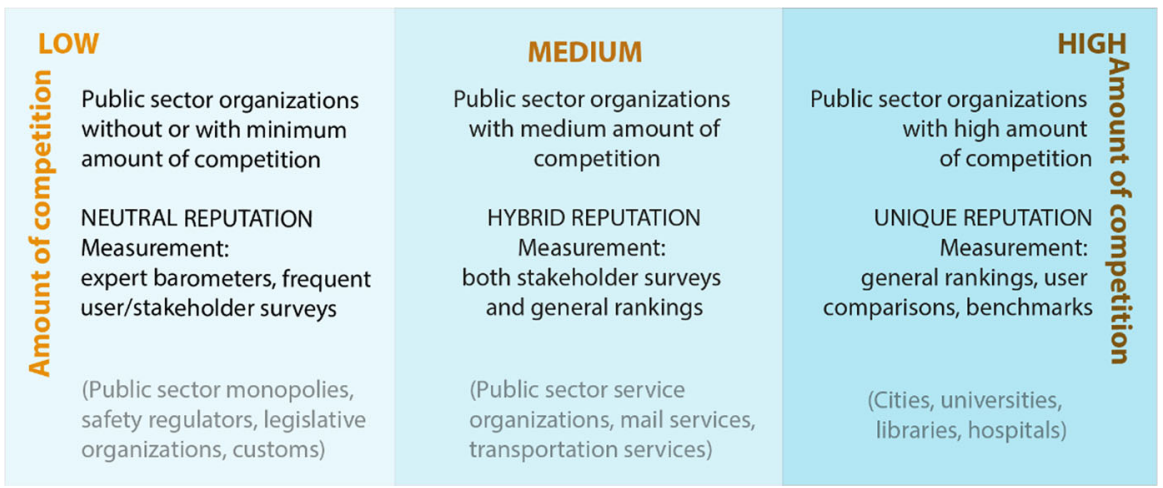

Fig. 1 Measurement of reputation according to public sector organization types (Canel and Luoma-aho 2019, 130) 
implement in the organizations if they were the manager, but little research has compared existing reputation measures with the results of the Net Promoter Score.

\section{Netpromoter score}

To solve the challenges of legibility of different measures due to service types in the public sector, simple comparable measures have been suggested. Among these is the Net Promoter Score, originally created for business organizations. Net Promoter score (NPS) is a tool for organizations to measure the overall impression and reputation. Similar to stakeholder engagement measures (Johnston and Taylor 2018), the NPS respondents classify according to different groups: those who support (promoters), those who do nothing (passives) and those who harm the organization (detractors) (Reichheld 2003). According to its developers, the NPS working system needs three fundamental elements: systematic data collection, closed loop learning process and a target of increasing the number of promoters (Reichheld and Markey 2011).

In practice, NPS data is collected via the question: "On a scale of $0-10$, how likely is that you would recommend this organization to a friend or colleague?". Those who answer 9-10 are promoters, 7-8 are passives and 0-6 are viewed as detractors. The logic behind such classification is that only those who are very happy $(9,10)$ are likely to recommend the experience or product. Further, those who are very unhappy (0-6) are likely to warn about the experience or product. However, those without strong good or bad experiences (7-8) are likely not to do anything. The NPS score results from taking the percentage of promoters subtracted by the percentage of detractors. The passives are excluded from the equation, but their role remains significant in the sense that they may activate in either direction: become promoters or detractors (Reichheld 2003).

The NPS is easy to use for both citizens and public officials, and provides easy comparisons between organizations. Though it is simple, early uses of NPS in the public sector context suggest that NPS could be used as a starter for more deeper comparisons between different stakeholder groups' satisfaction (Vochin et al. 2020). Further, it is a tool easy for public managers as well, and helps set clear targets for operations (Reichheld 2003).

The NPS has been criticized by scholars and practitioners alike due to its oversimplifications of a complex phenomenon and its fit with the nature of public services (Kristensen and Eskildsen 2014). Further, it is important to distinguish whether we are measuring political or non-political public sector organizations. For NPS in the political context, the score could reflect merely how well the individuals agree with the political party message, whereas for public sector organizations, the NPS would measure how individuals feel about the organization or public sector in general. Depending on the case, NPS could actually reflect either 1) how well the individual agrees with the message of the organization or party; 2) how well the organization or party has performed; or 3) how well the organization or party has communicated about themselves; or even 4) how the individual feels about the leaders of the party or organization. For political organizations, more emphasis would be placed on the leaders and ideals behind the organization, but in practice the NPS mixes all attributes of assessment without distinguishing where the score results from. 
In fact, Canel and Luoma-aho conclude that "Although the measure is simple enough for almost all public sector organizations to apply it, there are certain challenges to using the NPS in the public sector, as most services are not freely chosen, and some services (taxation and law enforcement, for example) may in fact go against the individual citizen's personal wishes, making reputation measurement inappropriate" (Canel and Luoma-aho 2019, 129). With these challenges in mind, we next turn to comparing the Net Promoter Score with more traditional reputation measures through the analysis of stakeholders' assessments about one large Finnish ministry and several organizations under its domain.

\section{Testing out the net promoter score in the public sector}

Previous studies (already cited in this manuscript) were addressed to compare and describe how well the NPS would match public sector reputation. As a first attempt to compare these measures, the hypotheses were kept simple. Based on the previous studies and understanding of the NPS, the following hypotheses were set:

- Hypothesis 1) The greater the NPS given by the individual to the organization, the better they evaluate the overall reputation of the organization to be (Reichheld 2003).

- Hypothesis 2) Promoters have more positive experiences of the organizations (Reichheld 2003).

- Hypothesis 3) Detractors expect more change from the organization than promoters (Reichheld 2003).

- Hypothesis 4) Promoters evaluate the public image of the organizations more positively than detractors (Reichheld 2003).

- Hypothesis 5) Promoters spread more positive WOM than detractors (Berger 2014).

- Hypothesis 6) Detractors spread more negative WOM than the promoters (Berger 2014).

- Hypothesis 7) Passives do not spread WOM (Reichheld 2003).

- Hypothesis 8) Regular WOM is more popular than Social WOM among public sector organizations' stakeholders (Eisingerich et al. 2015).

The data was collected via an online reputation survey (Appendix 1) sent out to 3400 respondents representing frequent stakeholders of public sector organizations under the field of the largest ministry in Finland. The public sector and its institutions in Finland are especially strong, as Finland is considered to be a Nordic welfare state where many public services are universally accessible to all citizens, not needs based. The universality of public services has been linked with high amount of generalized trust in society: when citizens trust their public sector, they tend to trust each other as well (Rothstein and Uslaner 2005). Measures of social trust are high, and corruption is rare in Finland, and administrative public sector organizations serve as separate institutions merely guided by political decision makers.

The respondents were stakeholders that frequently had contact with public organizations, as their view was believed to be more helpful for development as they had actual experiences and knowledge of the organizations. The questionnaire (Appendix 
1) followed the design of previous validated reputation measurement tools for public sector reputation (Luoma-aho 2007, 2008, see Appendix 1), with an addition of the NPS question toward the end of the questionnaire. Though several years old, the 2014 data was chosen because it was the first measurement time the respondents saw the new NPS in the otherwise frequent reputation survey that they were familiar with since 2003. Overall, there were 1198 respondents, yielding a response rate of $35,2 \%$.

Though Net Promoter Score itself is an interval scale, it was transformed into a nominal scale to enable tests. Respondents providing the recommendation numbers 1-6 were coded as detractors, 7-8 as passives and 9-10 as promoters (Reichheld 2003). Out of all the respondents, $51 \%$ were female and $47 \%$ male and rest undisclosed. The mean of the respondents' age was 51 years, and they were mostly experts or managers and employees. As the data was not normally distributed but leaned toward the positive on the 1-5 scale, nonparametric tests (eg. Kruskal-Wallis test) were utilized for the analyses.

\section{Results: Comparing reputation and NPS scores in the public sector}

To begin, the Net Promoter score was calculated for the data. There were 51,5\% of promoters, and 14,3\% detractors, yielding 37,2 as the netpromoter score. This can be considered quite a good score, as many businesses struggle to get a positive score. The promoters were mostly employees (56,5\% of employees) and experts $(56,8 \%$ of experts), whereas the detractors were mostly top managers $(21,8 \%)$, but even top managers were more often promoters $(40,6 \%)$ than detractors. Surprisingly, frequency of contact, age or gender did not show significant differences when it came to the NPS categories.

\subsection{Reputational factors (hypothesis 1)}

This study applied the reputation measurement developed for public sector organizations (Luoma-aho 2008), and the means counted for each reputational factor (authority, esteem, trust, and service efficiency) of the survey were next correlated with the NPS via Kruskal-Wallis. Significant differences existed on all factors between both groups, as promoters evaluated all factors above the average, while detractors evaluated the lowest in all the reputational factors. The most significant differences $(p=0,000)$ between the groups were found on the factor trust: promoters' mean was 4,5, while detractors' mean was 3,2 and passives' 4,0. Therefore data confirm Hypothesis 1 by which the greater the NPS given by the individual to the organization, the better the overall reputation of the organization is evaluated.

\subsection{Experiences (hypothesis 2)}

To see how the net promoter score matched with overall reputation among the stakeholders, first the experiences reported by the stakeholders were cross tabulated and Chi-Square test was performed. The connection between stakeholder's experiences and NPS values was statistically very significant $(p=0,00): 89,3 \%$ of the "mainly negative experiences" answers came from detractors, and $72,8 \%$ of the mainly positive 
answers came from promoters. Furthermore, $44 \%$ of neutral experiences came from the passive group. Still, despite the statistically highly significant differences, each group contained some stakeholders who reported their experiences to be a mix of both negative and positive or neutral. Interestingly, $50 \%$ of those who reported not to really have any experiences came from the detractor group, meaning that some detractors actually had very few experiences.

\subsection{Expectations (hypothesis 3)}

Next, the expectations that individuals had towards the future actions of the organizations were compared with the NPS. Chi-Square test showed a highly significant connection $(p=0,00)$ between expectations and the NPS. The division was obviousfrom the promoters' point of view. 50,9\% of the promoters would keep the organization's actions the same, while 36,1\% expected change. On the other hand, $72,7 \%$ of detractors expected change, with only $4 \%$ keeping the status quo. In addition, over half of the passives (54\%) expected change, and 20,6\% would keep the actions the same.

\subsection{Public image (hypothesis 4)}

A central factor of reputation is what is reported publicly, and the NPS was compared with the stakeholders' evaluations of the organizational public image. There was a correlation (Chi-Square $p=0,00$ ), and the promoters reported mostly a positive image $(61,2 \%)$. Interestingly, $32,3 \%$ of detractors reported the image to be neutral, and $23,4 \%$ reported no clear image had been formed, but $13,2 \%$ of detractors said the image was mostly negative.

\subsection{WOM (hypotheses 5-8)}

Next, the WOM reputation survey data ("I have told others about my positive / negative experiences via...", see questionnaire in Appendix 1) was compared with the NPS. Again, there was a strong correlation between the WOM practices of the stakeholders and NPS: Chi-Square test showed highly significant correlation between the variables $(p=0,000)$. Altogether $93,2 \%$ of the promoters had shared some sort of positive WOM (PWOM), 69,2\% of detractors had shared negative WOM (NWOM). Interestingly, positive WOM was shared among all groups, though merely in smaller quantities and in fewer channels among the detractors and neutrals.

There were clear differences in how positive WOM was shared: the more positive the stakeholders, the more channels they utilized: For positive WOM, promoters utilized all 5 channels (direct to organization, privately among friends and family, at the workplace, publicly in social media and publicly via traditional media), whereas detractors sharing less positive feedback utilized only 2 channels. Promoters shared positive WOM mostly in their own workplace $(87 \%)$ or straight to the organization $(57,7 \%)$, but also among their family and friends (40,2\%). Publicly sharing PWOM was not common, as only 3,8\% of the promoters had shared via social media, and $5,1 \%$ had shared through legacy media (Moreover: correlations were less significant between the NPS and public sharing: social media $(p=0,042)$ and traditional media $(p=0,037))$. 
Altogether 53,5\% of all respondents had shared NWOM. Though sharing negative WOM (NWOM) was more common with detractors $(69,2 \%)$, also promoters $(44 \%)$ and passives $(61,3 \%)$ had shared negative WOM $(p=0,00)$. Similarly to PWOM, $59,8 \%$ of detractors shared NWOM mainly at their own workplace $(p=0,00)$ or straight to organization $(34,9 \%, p=0,002)$, or among family and friends $(24,9 \%, p=$ $0,003)$. Passives also shared NWOM, as 52,9\% $(p=0,00)$ had shared NWOM in the workplace, $31,3 \%(p=0,002)$ had shared NWOM to organization, and 16,4\% ( $p=$ 0,003 ) had shared NWOM with family and friends.

\section{Discussion}

Measuring intangible assets is becoming a norm for public sector organizations (Canel and Luoma-aho2019), and this research attempts to contribute in the entailed challenge. As most measures of intangible resources are very complex, scholars have called for simple measures suitable for the public sector (Bourgon 2009). This study looked at the suitability of the such measurement tool, the Net Promoter Score (NPS) for public sector organizations. Altogether, eight hypotheses were formed based on earlier studies, and they were tested out in practice on stakeholder survey data on frequent stakeholders evaluating eleven Finnish public sector organizations.

Overall, the results seem to conclude that the NPS yields very similar results as more complex reputation measurements, and for that part could seem to be a good addition for public sector organizations' measurement portfolios, with some nuances tailored to the public sector context. The biggest differences include lack of competition, difficulty of comparability across organizations and sectors as well as the careful selection of respondents when it comes to organizations not known by the general public. With these in mind, the hypotheses are next discussed.

The first hypothesis (1) suggested that the greater the NPS given by the individual to the organization, the better they evaluate the overall reputation of the organization. Hypothesis 1 was confirmed, as the promoters gave more positive evaluations throughout. Of special interest was the reputational factor Trust, where the differences between detractors and promoters were the greatest: what really differentiates these two groups seems to be related to trust or lack of trust when it comes to reputation evaluation. Though the phenomenon is sure to be more complex, previous studies have confirmed the relevance of (dis)trust in exploring how stakeholders see public sector organizations (Rothstein and Uslaner 2009; Canel and Luoma-aho2019; Luoma-aho2008; Wæraas and Byrkjeflot 2012; Oomsels and Bouckaert 2014; Oomsels et al. 2019).

As for Hypothesis 2, it was proposed that the promoters have overall more positive experiences of the organizations than the detractors and passives. Hypothesis 2 was confirmed, as $72,8 \%$ of the mainly positive answers came from Promoters, and $89,3 \%$ of the "mainly negative experiences" answers came from detractors. Interestingly, each group contained all possible answers from positive, negative, neutral and mixed. Also, $50 \%$ of those who reported not to really have any experiences came from the detractor group, meaning that lack of experience might lead stakeholders to operate as detractor. This would imply that when it comes to experiences, the differences between the groups in the public sector are not that clear, and the NPS in the public sector is actually a combination of several different experiences. Previous studies have noted 
similar challenges, as public services are complex entities for stakeholders to evaluate clearly (Thijs 2011). Hence, further studies should keep in mind that the NPS in the public sector does not thoroughly reflect the complex nature of stakeholders' experiences, and detractors and promoters may have both good and bad experiences.

Hypothesis 3 focused on expectations, as it suggested that the detractors expect more change from the organization than promoters, due to their dissatisfaction with the organization in question. Hypothesis 3 was confirmed, as $72,7 \%$ of detractors expected change. Interestingly, promoters $(36,1 \%)$ and passives $(54 \%)$ also expected change, which is in line with the literature that suggests that there is no longer a status quo for the public sector, but instead continuous change according to different societal transformations and expectations (Canel and Luoma-aho 2019).

Reputation is often linked to the impression that the media provide about the organizations, and meditatization has become a current challenge for all public sector entities (Fredriksson and Pallas 2020). Hypothesis 4 was confirmed as the promoters reported mostly a positive image $(61,2 \%)$. Interestingly, detractors were not as negative as expected, but instead just like in the case of experiences, they reported the image to be neutral $(32,3 \%)$ or lacking $(23,4 \%)$ in the sense that no clear image had actually been formed in their opinion. This would point to the same challenge discussed above, mainly the stakeholders lacking of experiences showing up in the detractor group. This could be due to the nature of the public sector organizations measured here. For media image, this would imply that, without a clear image, many organizations may end up being categorized worse than they are, potentially due to a stigmatic sector reputation (Luoma-aho 2007), challenge of evaluating a complex phenomenon (Thijs 2011; Wæraas and Byrkjeflot 2012), and the increased need to have a media presence (Fredriksson and Pallas 2020). Whether this will lead to positive increase of visibility through good actions and communication or merely increased impression management, remains to be seen.

Of all the reputational measures, data suggest that WOM is the closest to the NPS, and hence the aim of growing the number of NPS would be all about growing the number of those who spread positive WOM (Reichheld and Markey 2011). Hypothesis 5 suggested the promoters to spread more positive WOM than detractors, and it was confirmed: Altogether 93,2\% of the promoters had shared some sort of positive WOM (in short: PWOM). Interestingly, PWOM was shared among all groups, merely in smaller quantities and in fewer channels among the detractors and neutrals. This is in line with previous studies as well, as East et al. (2011) suggested that also negative stakeholders would share PWOM (East et al. 2011).

It seems that the more positive the stakeholders, the more channels they utilized for WOM: For positive word of mouth, promoters utilized all 5 channels (direct to organization, privately among friends and family, at the workplace, publicly in social media and publicly via traditional media). The most popular channel for promoters to share PWOM was their workplace (87\%) or directly to the organization $(57,7 \%)$. In addition, it seems WOM travels beyond its work context to also the greater networks of the stakeholders, as PWOM was surprisingly much share also among their family and friends $(40,2 \%)$. This highlights the dynamic nature of stakeholders in the public sector- individuals without personal experience can have an opinion about the organization for better or worse (Luoma-aho et al. 2020). As for NWOM (negative word of mouth), literature suggested that it may spread faster 
than PWOM, but it seems that with all channels in use, the spread of PWOM is quite strong in this case.

Hypothesis 6 proposed that the detractors spread more negative WOM than the promoters. Hypothesis 6 was confirmed, as $69,2 \%$ of detractors had shared negative WOM (NWOM). Interestingly, over half of all the respondents to this study $(53,5 \%)$ had shared NWOM about the organization: also, promoters $(44 \%)$ and passives $(61,3 \%)$ had shared. The number of channels used for NWOM was fewer than PWOM. Yet, similarly to PWOM, 59,8\% of detractors shared NWOM mainly at their own workplace or straight to organization $(34,9 \%)$, but also among family and friends $(24,9 \%$,$) . The faster spread of NWOM could hence be compensated by the fewer$ channels utilized by the stakeholders. Previous studies suggested that the NPS does not measure NWOM as well as it measures PWOM (East et al. 2011), and this seemed the case here as well.

Hypothesis 7 suggested that the passives do not spread WOM. Hypothesis 7 was not confirmed, as the passives shared both PWOM as well as NWOM. In fact, 52,9\% had shared NWOM in the workplace, $31,3 \%$ had shared NWOM to organization and $16,4 \%$ had shared NWOM with family and friends. This finding is different from the origins of NPS (Reichheld 2003), where it was suggested that passives are 'passively satisfied' and lack action therefore. It seems that public sector stakeholders are somewhat different in this matter, as passives were more like promoters than detractors.

Hypothesis 8 suggested that regular WOM was more popular than Social WOM among public sector organizations' stakeholders. Hypothesis 8 was confirmed, as publicly sharing online PWOM was not common: only 3,8\% of the promoters had shared via social media, and $5,1 \%$ had shared through legacy media, and no significant differences were found between the groups on social media sharing. Previous literature suggested social WOM (SWOM) to be more influential than traditional face-to-face WOM (Sun et al. 2006), but that the threshold for sharing social was higher on SWOM than WOM (Eisingerich et al. 2015). This study seems to support earlier findings, and the reasons for the lack of SWOM have been suggested to be due to perceived social risk, as sharing sWOM can be seen as more sensitive and durable in nature (Eisingerich et al. 2015.). The use of social networks of public sector organizations' stakeholders does not allow to claim for now that a NPS in the public sector needs to explore and include the effect of social interaction in the Internet.

\section{Conclusion: Public sector net promoter score}

This research has looked at how stakeholders see public sector organizations and services in a way that yields measures which are simple and legible. Further, new measures needed to take into account the increasingly digitalized stakeholders, and help with the challenges of measuring reputation and performance in the public sector. We borrowed the Net Promoter Score from the private sector to build conceptual links with reputation assessment, and tested these relations with data from one ministry's stakeholders in Finland. In result, we conclude Net Promoter Score to produce results comparable and similar with more complex reputation measurements, but to lack some sector specific traits that matter how reputation is formed. Hence, we understand that the NPS as such needs to be adapted to suit the public sector context. 
Building on the ideal of neutral reputation (Luoma-aho 2007) and the findings of our study, we propose a new measure: Public Sector NPS, PSNPS. As our results point to the 'passives' being anything but passive, and in our data passives are more likely to promote than detract, we propose that for PSNPS, the group of passives should be included in the promoters. In fact, the passives had mainly a neutral image of the measured organizations.

Further, the detractors in the public sector are somewhat different from those in the private sector. According to our findings, many detractors are willing to contribute ideas to how the organizations need to change. Thus in public sector organizations, for PSNPS the stakeholders would only be divided into two groups: promoters and detractors; or as they have been called in the public sector context: Faith-holders and Hateholders (Luoma-aho 2007, 2015).

Therefore, we propose PSNPS to be formed accordingly: Taking together those who answer 7 or 8 (NPS neutrals), and those who answer 9 or 10 (NPS promoters) and summing them up as extended promoters, and keeping those who answer 1-6 as detractors (NPS detractors). Therefore, for this study, the PSNPS could be counted as $85,66 \%-14,33 \%=71,33 \%$. Though this PSNPS of 71 is a first of its kind, it is a very positive one. This could partly be explained by the high levels of trust in society, lack of corruption and credibility of authorities in Finland (confirmed by European Social Survey). Clearly more studies are needed to check whether PSNPS would work in different cultural settings and in various degrees of public sector organizations. It is hoped that future studies could also determine where the global mean for PSNPS would land.

PSNPS mixes all attributes of assessments without distinguishing where the score results from, and empirical research would help exploring where the sources are. More studies are also needed to go in depth into the potential changes needed to adjust the PSNPS to the specific dilemmas of public sector reputation management mentioned in this paper (political nature of the context, consistency, charisma, uniqueness and excellence, Wæraas and Maor 2015). Future studies could also hypothesize, whether PSNPS could reflect the communication of the leaders of the public organizations measured, and how organization's financial performance shapes the PSNPS. Future studies on PSNPS should also establish the margin within which public sector organizations should best attempt to reach among their stakeholders, and discuss the challenge of end-users" "loyalty" in the public sector. Finally, further research should explore to what extent a PSNPS might help assessing the capacity of public sector organizations to explore the overall impression and reputation their stakeholders hold, and to consequently, develop governmental programs to address both the needs of promoters and detractors.

Though much of public sector reputation may today form online, our results point to the stakeholders not sharing very openly their experiences with the public sector online. In addition, regarding social interaction via the Internet, results do not seem to support the idea that reputation is increasingly formed through social networking sites, but rather stresses the suggestion that what happens online is not always the same as offline (Eisingerich et al. 2015). This would lead to the understanding that there could in fact be two different realms for public sector reputation: the one online and the other offline. Further, our data points out that 
when it comes to sharing experiences of public sector organizations among stakeholders, social media does not yet seem to be the major source for reputation formation. Knowing this gives more time for public sector organizations to organize their communication accordingly, and prepare for future needs as social media gaines more ground.

A first in its kind, the study has several limitations that should be acknowledged. First, the study took two existing measure (public sector reputation survey tool \& NPS) and tested them in the public sector context, whereas constructing a totally novel sector-specific recommendation tool might have been more adequate. Not all the nuances of the public sector were analyzed, and future studies should build on more robust comparisons. On the other hand, the reputation tool utilized here was constructed especially for public sector context (Luoma-aho 2007, 2008), making the comparison with the industry originated NPS possible and useful. Second, as reputation surveys are often tailored according to organizational needs, it needs to be further tested whether the PSNPS would be as similar to reputation barometers of different types of public sector organizations. Third, the hypotheses set for the study were kept quite basic as to lay the foundation for this first attempt of comparisons, but future studies should take a more ambitious approach. Fourth, more detailed and qualitative studies are needed to understand whether the recommendation that individuals give out on public sector organizations is formed the same way as reputation. Further, the dataset analyzed is limited to one country, Finland, and generalizations of these specific findings must be taken in its context. International studies to compare reputation and test the PSNPS are needed. Future studies are also needed to address potential cultural differences between the promoters and detractors.

In addition, it should be remembered that not all public sector stakeholders need to be satisfied with the services. For example, a negative PSNPS could actually represent a well functioning public sector organization, if the stakeholders answering would be caught criminals evaluating the police. Further, future studies should address PSNPS fit with other measurement tools and the ethical considerations necessary when measuring and understanding PSNPS. Despite these challenges, we feel that a simple indicator such as the PSNPS proposed here is a step forward in the endeavor of finding new ways of measuring the intangible value of public sector organizations to show the value that they provide to society and the satisfaction of their different stakeholders (Canel et al. 2020). 


\section{Appendix 1: Survey questionnaire sent to frequent stakeholders of the public sector organizations studied}

Please state in a few words or adjectives what first comes to your mind about the case organization?

Next $\mathrm{i}$ would like to ask you to rate the case organization through various statements. Please consider each statement as to how well it describes it. Choose the number that describes your opinion the best.

\begin{tabular}{|c|c|}
\hline not responsive & responsive \\
\hline not customer oriented & customer oriented \\
\hline closed & open \\
\hline static & dynamic \\
\hline bureaucratic & flexible \\
\hline distant & humane \\
\hline dictative & conversational \\
\hline old fashioned & modern \\
\hline doesn't listen & listens \\
\hline $\begin{array}{l}\text { doesn't improve } \\
\text { operations }\end{array}$ & improves operations \\
\hline not appreciated & appreciated \\
\hline reacts afterwards & anticipatory \\
\hline $\begin{array}{l}\text { not internationally } \\
\text { appreciated }\end{array}$ & $\begin{array}{l}\text { internationally } \\
\text { appreciated }\end{array}$ \\
\hline $\begin{array}{l}\text { makes irrelevant } \\
\text { research }\end{array}$ & $\begin{array}{l}\text { make relevant } \\
\text { research }\end{array}$ \\
\hline unmotivated staff & motivated staff \\
\hline undesirable job & desirable job \\
\hline behind in the field & trendsetter in the field \\
\hline biased & unbiased \\
\hline $\begin{array}{l}\text { works for vested } \\
\text { interest }\end{array}$ & $\begin{array}{l}\text { works for common } \\
\text { good }\end{array}$ \\
\hline unresponsible & responsible \\
\hline
\end{tabular}




\begin{tabular}{|c|c|}
\hline unethical & ethical \\
\hline unfair & fair \\
\hline unprofessional & professional \\
\hline unreliable & reliable \\
\hline passive & active \\
\hline $\begin{array}{l}\text { doesn't respect the } \\
\text { needs of stakeholders }\end{array}$ & $\begin{array}{l}\text { respects the needs } \\
\text { of stakheholders }\end{array}$ \\
\hline $\begin{array}{l}\text { doesn't communicate } \\
\text { clearly whot to contact if } \\
\text { needed }\end{array}$ & $\begin{array}{l}\text { communicates clear- } \\
\text { ly who to contact if } \\
\text { needed }\end{array}$ \\
\hline low quality & high quality \\
\hline unreachable & reachable \\
\hline useless & usefull \\
\hline $\begin{array}{l}\text { doesn't meet } \\
\text { expectations } \\
\text { doesn't operate with } \\
\text { clear principles }\end{array}$ & $\begin{array}{l}\text { meets expectations } \\
\text { operates with clear } \\
\text { principles }\end{array}$ \\
\hline $\begin{array}{l}\text { provides information } \\
\text { that is hard to exploit }\end{array}$ & $\begin{array}{l}\text { provides information } \\
\text { that is easy to exploit }\end{array}$ \\
\hline ineffictive & effective \\
\hline poorly managed & well managed \\
\hline slow & fast \\
\hline $\begin{array}{l}\text { doesn't stay on } \\
\text { schedule }\end{array}$ & stays on schedule \\
\hline $\begin{array}{l}\text { communicates } \\
\text { objectives unclearly }\end{array}$ & $\begin{array}{l}\text { communicates } \\
\text { objectives clearly }\end{array}$ \\
\hline fragmented & coherent \\
\hline
\end{tabular}

what school grade (4-10) would you give to organizations operation?

$\begin{array}{lllllllllllllll} & 4 & 4,5 & 5 & 5,5 & 6 & 6,5 & 7 & 7,5 & 8 & 8,5 & 9 & 9,5 & 10 & \\ \text { poor } & \bigcirc & \bigcirc & \bigcirc & \bigcirc & \bigcirc & \bigcirc & \bigcirc & \bigcirc & \bigcirc & \bigcirc & \bigcirc & \text { excellent }\end{array}$ 
Next we ask you to tell about your understanding about the organization

My experience about organization are mainly:
negative
neutral
positive
both positive and negative
i have no experiences

I have told about positive experience about the organization (choose all the alternatives that desccribes your actions):

$\square$ Straight to the organization (via contact persons, representatives or feedback channels)

$\square$ privately (to my friends, family)

$\square$ in my work place (collegues or supervisor)

$\square$ publicly (in social media)

$\square$ publicly via media (i.e. radio-, TV or newspaper interviews or writings)

$\square \quad \mathrm{i}$ haven't told about my positive experiences to anyone

$\square$ i don’t have positive experiences

I have told about negative experience about the organization (choose all the alternatives that desccribes your actions):

Straight to the organization (via contact persons, representatives or feedback channels) privately (to my friends, family)

in my work place (collegues or supervisor)

publicly (in social media)

$\square$ publicly via media (i.e. radio-, TV or newspaper interviews or writings)

$\square$ i haven't told about my negative experiences to anyone

$\square$ i don't have negative experiences 
My expectations towards the organization in the future

operations should stay the same

i don't have special expectations

If I could freely change the organizations operations, I would change:

What kind of image has the case organization acquired in public eye?

most of the time negative

neutral

most of the time positive

both positive and negative

no clear image in public

something else, what?

In the choose the information about yourself for statistics.

Gender:

Male

Female

Age (in years) years old

I have contact with the case organization:
weekly
monthly
yearly
rarely than yearly 
Position:

employee/ official

middle management

top management

expert/specialist

entrepreneur

Area, province:

southern Finland

eastern Finland

western Finland

Oulu province

Lapland province

something else, what?

My image about the organization are mainly transformed

in personal meetings (meetings, own work, inspections, training)

by electric connections (internet, email, campaigns)

by social media (Facebook, Twitter, blogs)

by publications (books, magazines, stories, prochures, advertisements)

by media (radio, tv, newspapers)

How likely would you recommend cooperation with the organization to your collegues?

$\begin{array}{llllllllll}1 & 2 & 3 & 4 & 5 & 6 & 7 & 8 & 9 & 10\end{array}$

not likely $\bigcirc \bigcirc \bigcirc \bigcirc \bigcirc \bigcirc \bigcirc \bigcirc \bigcirc \bigcirc$ extremely likely

Feedback for the questionnaire:

Thank you for your valuable help! 


\section{Appendix 2: The Chi-Squared tests for all hypotheses}

Hypotheses

Hypothesis 1) The greater the NPS given by the individual to the organization, the better Table 1 . they evaluate the overall reputation of the organization to be

Hypothesis 2) Promoters have more positive experiences of the organizations

Table 2 .

Hypothesis 3) Detractors expect more change from the organization than promoters

Table 3.

Hypothesis 4) Promoters evaluate the public image of the organizations more positively Table 4. than detractors

Hypothesis 5) Promoters spread more positive WOM than detractors.

Table 5.

Hypothesis 6) Detractors spread more negative WOM than the promoters

Table 6

Hypothesis 7) Passives do not spread WOM.

Tables 5 and 6.

Hypothesis 8) Regular WOM is more popular than Social WOM among public sector organizations' stakeholders.

Results reported in text

Table 1 Reputation factors and Net Promoter score

\begin{tabular}{|c|c|c|c|c|}
\hline & $\mathrm{N}$ & Mean & Std. Deviation & Std. Error \\
\hline \multicolumn{5}{|l|}{ Authority } \\
\hline 1. Detractor & 137 & 23,933 & ,67,223 &, 05743 \\
\hline 2. Passive & 345 & 31,630 & $, 55,173$ & ,02970 \\
\hline 3. Promoter & 541 & 36,732 & $, 58,075$ & ,02497 \\
\hline Total & 1023 & 33,297 & $, 72,814$ & ,02277 \\
\hline \multicolumn{5}{|l|}{ Esteem } \\
\hline 1. Detractor & 138 & 28,188 & $, 59,040$ & ,05026 \\
\hline 2. Passive & 3334 & 34,311 & $, 46,304$ & ,02534 \\
\hline 3. Promoter & 530 & 39,124 & $, 54,034$ & ,02347 \\
\hline Total & 1002 & 36,014 & $, 64,701$ & ,02044 \\
\hline \multicolumn{5}{|l|}{ Trust } \\
\hline 1. Detractor & 162 & 32,469 & ,75,207 & ,05909 \\
\hline 2. Passive & 389 & 39,596 & $, 55,456$ & ,02812 \\
\hline 3. Promoter & 587 & 44,583 & $, 51,995$ & ,02146 \\
\hline Total & 1138 & 41,154 & $, 70,769$ & ,02098 \\
\hline \multicolumn{5}{|l|}{ Service } \\
\hline 1. Detractor & 158 & 27,532 & $, 61,534$ & ,04895 \\
\hline 2. Passive & 377 & 34,984 & $, 49,757$ & ,02563 \\
\hline 3. Promoter & 585 & 40,482 & $, 50,996$ & ,02108 \\
\hline Total & 1120 & 36,805 & $, 68,944$ & ,02060 \\
\hline
\end{tabular}

Efficiency 
Table 1 (continued)

\begin{tabular}{lllll}
\hline & $\mathrm{N}$ & Mean & Std. Deviation & Std. Error \\
\hline 1. Detractor & 156 & 25,064 & $, 60,490$ &, 04843 \\
2. Passive & 374 & 31,511 & $, 57,228$ &, 02959 \\
3. Promoter & 584 & 37,072 & $, 62,755$ &, 02597 \\
Total & 1114 & 33,523 & $, 73,958$ &, 02216 \\
\hline
\end{tabular}

Kruskal-Wallis test $p=0,000$

Table 2 Cross tabulation experiences about the case organization and NPS

\begin{tabular}{|c|c|c|c|}
\hline & Detractor & Passive & Promoter \\
\hline \multicolumn{4}{|l|}{ My experiences are } \\
\hline \multicolumn{4}{|l|}{ Mainly negative } \\
\hline Count & 25 & 3 & 0 \\
\hline$\%$ within my experiences are & $89,3 \%$ & $10,7 \%$ & $0,0 \%$ \\
\hline Within Net Promoter score & $14,9 \%$ & $0,7 \%$ & $0,0 \%$ \\
\hline \multicolumn{4}{|l|}{ Neutral } \\
\hline Count & 46 & 63 & 33 \\
\hline$\%$ within my experiences are & $32,4 \%$ & $44,4 \%$ & $23,2 \%$ \\
\hline Within Net Promoter score & $27,4 \%$ & $15,7 \%$ & $5,5 \%$ \\
\hline \multicolumn{4}{|l|}{ Mainly positive } \\
\hline Count & 10 & 165 & 468 \\
\hline$\%$ within my experiences are & $1,6 \%$ & $25,7 \%$ & $72,8 \%$ \\
\hline Within Net Promoter score & $6,0 \%$ & $41,1 \%$ & $77,4 \%$ \\
\hline \multicolumn{4}{|l|}{ Both positive and negative } \\
\hline Count & 79 & 164 & 102 \\
\hline$\%$ within my experiences are & $22,9 \%$ & $47,5 \%$ & $29,6 \%$ \\
\hline Within Net Promoter score & $47,0 \%$ & $40,9 \%$ & $16,9 \%$ \\
\hline \multicolumn{4}{|l|}{ I don't have experiences } \\
\hline Count & 8 & 6 & 2 \\
\hline$\%$ within my experiences are & $50,0 \%$ & $37,5 \%$ & $12,5 \%$ \\
\hline Within Net Promoter score & $4,8 \%$ & $0,5 \%$ & $0,3 \%$ \\
\hline
\end{tabular}

Chi-Square test $p=0,000$ 
Table 3 Cross tabulation of expectations towards the case organization and NPS

\begin{tabular}{llll}
\hline & Detractor & Passive & Promoter \\
\hline $\begin{array}{l}\text { My expectations towards the organization in the future: } \\
\text { Operation should stay the same }\end{array}$ & 6 & & \\
Count & $4,0 \%$ & 77 & 293 \\
$\%$ Within Net Promoter score & & $20,6 \%$ & $50,9 \%$ \\
I don't have have special expectations & 35 & 95 & 75 \\
Count & $23,3 \%$ & $25,4 \%$ & $13,0 \%$ \\
$\%$ Within Net Promoter score & & 208 \\
If I could freely change the organizations operations, I would & 109 & 202 & $36,1 \%$ \\
Count & $72,7 \%$ & $54,0 \%$ & \\
\% Within Net Promoter score & & & 208 \\
\hline
\end{tabular}

Chi-Square test $p=0,000$

Table 4 Cross tabulation of public image and NPS

\begin{tabular}{|c|c|c|c|}
\hline & Detractor & Passive & Promoter \\
\hline \multicolumn{4}{|c|}{ What kind of image has the case organization acquired in public eye: } \\
\hline \multicolumn{4}{|l|}{ Most of the time negative } \\
\hline Count & 22 & 12 & 13 \\
\hline$\%$ Within Net Promoter score & $13,2 \%$ & $3,0 \%$ & $2,2 \%$ \\
\hline \multicolumn{4}{|l|}{ Neutral } \\
\hline Count & 54 & 107 & 92 \\
\hline$\%$ Within Net Promoter score & $32,3 \%$ & $26,8 \%$ & $15,3 \%$ \\
\hline \multicolumn{4}{|l|}{ Most of the time positive } \\
\hline Count & 14 & 153 & 368 \\
\hline$\%$ Within Net Promoter score & $8,4 \%$ & $38,3 \%$ & $61,2 \%$ \\
\hline \multicolumn{4}{|l|}{ Both positive and negative } \\
\hline Count & 39 & 86 & 90 \\
\hline \% Within Net Promoter score & $23,4 \%$ & $21,6 \%$ & $15,0 \%$ \\
\hline \multicolumn{4}{|l|}{ No clear image } \\
\hline Count & 36 & 39 & 34 \\
\hline$\%$ Within Net Promoter score & $21,6 \%$ & $9,8 \%$ & $5,7 \%$ \\
\hline \multicolumn{4}{|l|}{ Something else } \\
\hline Count & 2 & 2 & 4 \\
\hline$\%$ Within Net Promoter score & $1,2 \%$ & $0,5 \%$ & $0,7 \%$ \\
\hline
\end{tabular}

Chi-Square test $p=0,000$

\section{Springer}


Table 5 Cross tabulation of positives count + NPS

\begin{tabular}{|c|c|c|c|}
\hline & Detractor & Passive & Promoter \\
\hline \multicolumn{4}{|l|}{ Positives count } \\
\hline \multicolumn{4}{|l|}{0} \\
\hline Count & 67 & 68 & 41 \\
\hline$\%$ Within Net Promoter score & $39,6 \%$ & $16,9 \%$ & $6,8 \%$ \\
\hline \multicolumn{4}{|l|}{1} \\
\hline Count & 58 & 135 & 166 \\
\hline$\%$ Within Net Promoter score & $34,3 \%$ & $33,5 \%$ & $27,3 \%$ \\
\hline \multicolumn{4}{|l|}{2} \\
\hline Count & 33 & 143 & 222 \\
\hline$\%$ Within Net Promoter score & $19,5 \%$ & $35,5 \%$ & $36,6 \%$ \\
\hline \multicolumn{4}{|l|}{3} \\
\hline Count & 8 & 52 & 153 \\
\hline$\%$ Within Net Promoter score & $4,7 \%$ & $12,9 \%$ & $25,2 \%$ \\
\hline \multicolumn{4}{|l|}{4} \\
\hline Count & 3 & 4 & 18 \\
\hline$\%$ Within Net Promoter score & $1,8 \%$ & $1,0 \%$ & $3,0 \%$ \\
\hline \multicolumn{4}{|l|}{5} \\
\hline Count & 0 & 1 & 7 \\
\hline$\%$ Within Net Promoter score & $0,0 \%$ & $0,2 \%$ & $1,2 \%$ \\
\hline
\end{tabular}

Chi-Square test $p=0,000$ 
Table 6 Cross tabulation of negatives count + NPS

\begin{tabular}{llll}
\hline & Detractor & Passive & Promoter \\
\hline $\begin{array}{l}\text { Negatives count } \\
0\end{array}$ & & & \\
$\quad$ Count & 52 & 156 & 340 \\
$\%$ Within Net Promoter score & $30,8 \%$ & $38,7 \%$ & $56,0 \%$ \\
1 & & & \\
Count & 54 & 121 & 128 \\
$\%$ Within Net Promoter score & $32,0 \%$ & $30,0 \%$ & $21,1 \%$ \\
2 & & & 102 \\
Count & 38 & 93 & $16,8 \%$ \\
$\%$ Within Net Promoter score & $22,5 \%$ & $23,1 \%$ & 36 \\
Count & & & $5,9 \%$ \\
$\%$ Within Net Promoter score & 21 & 30 & 1 \\
4 & $12,4 \%$ & $7,4 \%$ & $0,2 \%$ \\
\hline Count & & 3 & \\
\hline Within Net Promoter score & $2,4 \%$ & $0,7 \%$ & \\
\hline
\end{tabular}

Chi-Square test $p=0,000$

Funding Open access funding provided by University of Jyväskylä (JYU).

Open Access This article is licensed under a Creative Commons Attribution 4.0 International License, which permits use, sharing, adaptation, distribution and reproduction in any medium or format, as long as you give appropriate credit to the original author(s) and the source, provide a link to the Creative Commons licence, and indicate if changes were made. The images or other third party material in this article are included in the article's Creative Commons licence, unless indicated otherwise in a credit line to the material. If material is not included in the article's Creative Commons licence and your intended use is not permitted by statutory regulation or exceeds the permitted use, you will need to obtain permission directly from the copyright holder. To view a copy of this licence, visit http://creativecommons.org/licenses/by/4.0/.

\section{References}

Bankins, S., \& Waterhouse, J. (2019). Organizational identity, image, and reputation: Examining the influence on perceptions of employer attractiveness in public sector organizations. International Journal of Public Administration, 42(3), 218-229.

Berger, J. (2014). Word of Mouth and interpersonal communication: a review and directions for future research. Journal of Consumer Psychology, 24(4), 486-607

Boon, J., \& Salomonsen, H. H. (2020). Public sector organizations and reputation. In V. Luoma-aho \& M. J. Canel (Eds.), Handbook of public sector communication (pp. 215-227). New York: Wiley-Blackwell.

Bourgon, J. (2009). New directions in public administration: Serving beyond the predictable. Public Policy and Administration, 24(3), 309-330. https://doi.org/10.1177/0952076709103813.

Canel, M., \& Luoma-aho, V. (2019). Public sector communication. Closing gaps between public sector organizations and citizens. Boston: Wiley.

Canel, M. J., Luoma-aho, V., \& Barandiarán, X. (2020). Public sector communication and public valuable intangible assets. In V. Luoma-aho \& M. J. Canel (Eds.), Handbook of public sector communication (pp. 101-114). New York: Wiley-Blackwell. 
Dahlberg, S., \& Holmberg, S. (2013). Democracy and bureaucracy: How their quality matters for popular satisfaction. West European Politics, 37(3), 515-537 www.tandfonline.com/doi/abs/10.1080/01402382. 2013.830468\#.Vc2bn03os50.

De Cnudde, S., \& Martens, D. (2015). Loyal to your city? A data mining analysis of a public service loyalty program. Decision Support Systems, 73, 74-84. https://doi.org/10.1016/j.dss.2015.03.004.

Deephouse, D. (2000). Media reputation as a strategic resource: An integration of mass communication and resource-based theories. Journal of Management, 26(6), 1091-1112.

Delli Carpini, M., Cook, F., \& Jacobs, L. (2004). Public deliberation, discursive participation, and citizen engagement. Annual Review of Political Science, 7, 315-344.

East, R., Hammond, K., \& Lomax, W. (2008). Measuring the impact of positive and negative word of mouth on brand purchase probability. International Journal of Research in Marketing, 25, 215-224

East, R., Romaniuk, J., \& Lomax, W. (2011). The NPS and the ACSI: A critique and an alternative metric. International Journal of Market Research, 53(3), 327-346.

Eisingerich, A. B., Chun, H. H., Liu, Y., Jia, H., \& Bell, S. J. (2015). Why recommend a brand face-to-face but not on facebook? How word-of-mouth on online social sites differs from traditional word-of-mouth. Journal of Consumer Psychology, 25(1), 120-128. https://doi.org/10.1016/j.jcps.2014.05.004.

Etter, M., Ravasi, D., \& Colleoni, E. (2019). Social media and the formation of organizational reputation. Academy of Management Review, 44(1), 28-52.

Fredriksson, M., \& Pallas, J. (2020). Public sector Communication \& Mediatization. In V. Luoma-aho \& M.-J. Canel (Eds.), The handbook of public sector communication (pp. 167-179).

Freeman, R. E., \& Reed, D. L. (1983). Stockholders and stakeholders: A new perspective on corporate governance. California Management Review., 25(3), 88-106.

Gelders, D., Bouckaert, G., \& van Ruler, B. (2007). Communication management in the public sector: Consequences for public communication about policy intentions. Government Information Quarterly, 24(2), 326-337. https://doi.org/10.1016/j.giq.2006.06.009.

Johnston, K., \& Taylor, M. (Eds.). (2018). The handbook of communication engagement. New York: Wiley Blackwell.

Kristensen, K., \& Eskildsen, J. (2014). Is the NPS a trustworthy performance measure? The TQM Journal, 26(2), 202-214. https://doi.org/10.1108/TQM-03-2011-0021.

Kuoppakangas, P., Suomi, K., Stenvall, J., Pekkola, E., Kivistö, J., \& Kallio, T. (2019). Revisiting the five problems of public sector organisations and reputation management-The perspective of higher education practitioners and ex-academics. International Review on Public and Nonprofit Marketing, 16(2), 147171.

Lee, D., \& Van Ryzin, G. G. (2019). Measuring bureaucratic reputation: Scale development and validation. Governance, 32, 177-192.

Luoma-aho, V. (2007). Neutral reputation and public sector organizations. Corporate Reputation Review, $10(2), 124-143$.

Luoma-aho, V. (2008). Sector reputation and public organizations. International Journal of Public Sector Management, 21(5), 446-467.

Luoma-aho, V., \& Canel, M. J. (2016). Public sector reputation. In Carroll CE (ed) SAGE encyclopedia of corporate reputation (pp. 597-600). SAGE Publications. https://doi.org/10.4135/9781483376493.n229

Luoma-aho, V. (2015). Understanding stakeholder thinking: faith-holders, hateholders and fakeholders. Institute for Public Relations Research Journal, Jan 7th. Available online: https:/instituteforpr.org/ understanding-stakeholder-engagement-faith-holders-hateholders-fakeholders/. Accessed 1 Jan 2021

Luoma-aho, V., Canel, M.-J., \& Sanders, K. (2019a). Global public sector and political communication. In D. Vercic (Ed.), Sriramesh, K (pp. 111-119). Routledge: The Global Public Relations Handbook.

Luoma-aho, V., Pirttimäki, T., Maity, D., Munnukka, J., \& Reinikainen, H. (2019b). Primed authenticity: How priming impacts authenticity perception of social media influencers. International Journal of Strategic Communication, 13(4), 352-365.

Luoma-aho, V., Olkkonen, L., \& Canel, M.-J. (2020). Public sector communication and citizen expectations and satisfaction. In V. Luoma-aho \& M.-J. Canel (Eds.), The handbook of public sector communication (pp. 303-314). Hoboken: Wiley-Blackwell.

Martin, S. (2017). Word-of-mouth in the health care sector: A literature analysis of the current state of research and future perspectives. International Review on Public and Nonprofit Marketing, 14(1), 35-56.

Munnukka, J., Maity, D., Reinikainen, H., \& Luoma-aho, V. (2019). "Thanks for watching.” the effectiveness of YouTube vlogendorsements. Computers in Human Behavior, 93(April), 226-234. https://doi.org/10. 1016/j.chb.2018.12.014. 
Oomsels, P., \& Bouckaert, G. (2014). Studying interorganizational trust in public administration: A conceptual and analytical framework for" administrational trust". Public Performance \& Management Review, 37(4), 577-604.

Oomsels, P., Callens, M., Vanschoenwinkel, J., \& Bouckaert, G. (2019). Functions and dysfunctions of interorganizational trust and distrust in the public sector. Administration \& Society, 51(4), 516-544.

Overman, S., Busuioc, M., \& Wood, M. (2020). A multidimensional reputation barometer for public agencies: A validated instrument. Public Administration Review, 80(3), 415-425.

Picci, L. (2012). Reputation-based governance and making states "legible" to their citizens. In Masum, H., \& Tovey, M. (Eds.). The reputation society (Chapter 13, pp. 141-150). The MIT-Press

Reichheld, F., Markey, R. (2011). The ultimate question 2.0: how net promoter companies thrive in a customer-driven world. Harvard Business Press

Reichheld, F. F. (2003). The one number you need to grow. Harvard Business Review, 81, 46-54.

Riege, A., \& Lindsay, N. (2006). Knowledge management in the public sector: Stakeholder partnerships in the public policy development. Journal of Knowledge Management, 10(3), 24-39.

Rothstein, B., \& Uslaner, E. (2005). All for all: Equality, corruption, and social trust. World Politics, 58(1), 41-72.

Rothstein, B., \& Uslaner, E. (2009). All for all: equality, corruption, and social trust. World Polit, 58(1), 4172. https://doi.org/10.1353/wp.2006.0022.

Sataøen, H. L., \& Wæraas, A. (2016). Building a sector reputation: The strategic communication of national higher education. International Journal of Strategic Communication, 10(3), 165-176. https://doi.org/10. 1080/1553118X.2016.1176567.

Sun, T., Youn, S., Wu, G., \& Kuntaraporn, M. (2006). Online word-of-mouth (or mouse): An exploration of its antecedents and consequences. Journal of Computer-Mediated Communication, 11(4), 1104-1127.

Sweeney, J., Soutar, G., \& Mazzarol, T. (2014). Factors enhancing word-of-mouth influence: Positive and negative service-related messages. European Journal of Marketing, 48(1), 336-359.

Thijs, N. (2011). Measure to improve: Improving public sector performance by using citizen-user satisfaction information. (0. Brussels: EUPAN / EIPA Retrieved from https://www.eupan.eu/wpcontent/uploads/2019/ 02/2010_2_BE_Measure_to_Improve_Improving_Public_Sector_Performance_by_Using_Citizen_ User_Satisfaction_Information.pdf. 1 Jan 2021

Vochin, O. A., Sârbu, M. A., Stanciu, S., \& Mansour, J. (2020). Implementing net promoter score in the public sector organizations. In R. Pamfilie, V. Dinu, L. Tăchiciu, D. Pleșea, \& C. Vasiliu (Eds.), 6th BASIQ international conference on new trends in sustainable business and consumption. Messina, Italy, 4-6 June 2020 (pp. 532-539). Bucharest: ASE.

Wæraas, A., \& Byrkjeflot, H. (2012). Public sector organizations and reputation management: Five problems. International Public Management Journal, 15(2), 186-206.

Wæraas, A., \& Maor, M. (Eds.). (2015). Organizational reputation in the public sector. London: Routledge.

Walker, K. (2010). A systematic review of the corporate reputation literature: Definition, measurement, and theory. Corporate Reputation Review, 12(4), 357-387.

Walker, R. M., Brewer, G. A., Boyne, G. A., \& Avellaneda, C. N. (2011). Market orientation and public service performance: New public management gone mad? Public Administration Review, 71(5), 707-717. https://doi.org/10.1111/j.1540-6210.2011.02410.x.

Zablah, A., Bellenger, D., \& Johnston, W. (2004). An evaluation of divergent perspectives on customer relationship management: towards a common understanding of an emerging phenomenon. Industrial Marketing Management, 33(2004), 475-489.

Publisher's note Springer Nature remains neutral with regard to jurisdictional claims in published maps and institutional affiliations. 